\title{
Woodland communities in the Chilean cold-temperate zone (Baker and Pascua basins): Floristic composition and morpho-ecological transition
}

\section{Comunidades leñosas en la zona chilena frío-templada (cuencas de los ríos Baker y Pascua): Composición florística y transición morfo-ecológica}

\author{
Osvaldo J. Vidal ${ }^{1}$, Jan R. Bannister ${ }^{1}$, Víctor Sandoval ${ }^{2}$, Yessica Pérez ${ }^{3}$ \& Carlos Ramirez ${ }^{4}$ \\ ${ }^{1}$ Institute of Silviculture, Faculty of Forest and Environmental Sciences, University of Freiburg, Tennenbacherstrasse 4, D-79106, \\ Freiburg im Breisgau, Germany. \\ ${ }^{2}$ Instituto de Manejo Forestal, Facultad de Ciencias Forestales y Recursos Naturales, Universidad Austral de Chile, Casilla 567, \\ Isla Teja, Valdivia. Chile. \\ ${ }^{3}$ Instituto de Botánica, Facultad de Ciencias, Universidad Austral de Chile, Casilla 567, Isla Teja, Valdivia. Chile. \\ ${ }^{4}$ Departamento de Ecología, Facultad de Ciencias Biologicas, Universidad Católica de Chile, Alameda 340, Santiago, Chile. \\ osvaldo.vidal@waldbau.uni-freiburg.de
}

\begin{abstract}
This study describes the floristic composition and morpho-ecological transition of woodlands along a climatic gradient in the southern cold temperate zone of Chilean Patagonia. A total of 256 phytosociological relevés were performed across a $150 \mathrm{~km}$ NE-SW transect to record vascular plant species. Classification (cluster analysis) and ordination (principal component analysis) techniques were used to segregate and examine the communities. Biodiversity indicators including richness and abundances of species natives and exotics, importance values, Raunkiaer plant life-forms, diversity indices and indicator species were calculated to describe community attributes. Beta diversity was analysed using the Jaccard index. Additionally, the current anthropogenic disturbances affecting this vegetation are discussed. In total, 11 woodland communities belonging to 3 morpho-ecological groups were segregated: a) meso-hygromorphic woodlands belonging to the Baker basin, mostly composed of deciduous forests containing relatively moderate values of richness and diversity but high richness of exotics, b) hygromorphic woodlands belonging to the southern segment of the Baker basin and along the Pascua basin, composed of evergreen forest containing the relatively highest values of richness and diversity and very low richness of exotics and c) high-Andean dwarf woodlands distributed at high elevations in both basins, composed of deciduous krummholz containing the lowest richness and diversity and no exotics. The replacement of deciduous by evergreen communities at low elevations occurs around the latitude $48^{\circ} \mathrm{S}$. Anthropogenic disturbances like logging by rural landowners, overgrazing by livestock and road construction are promoting biological invasions in the Baker basin forests, while the forests in the Pascua basin remain pristine since no human population occurs there.
\end{abstract}

KeYwords: Biogeographical transition, southern cold temperate zone, anthropogenic disturbances, pristine forests, Aysén.

\section{RESUMEN}

Este estudio describe la composición florística y la transición morfo-ecológica de las comunidades leñosas ocurriendo a través de un gradiente climático en la zona templada fría de la Patagonia chilena. Se establecieron un total de 256 relevamientos fitosociológicos a través de un transecto NE-SO de $150 \mathrm{~km}$ para registrar las especies de plantas vasculares. Técnicas de clasificación (análisis de conglomerados) y ordenación (análisis de componentes principales) fueron usadas para segregar y examinar comunidades. Se computaron indicadores de biodiversidad incluyendo riqueza y abundancia de especies nativas y exóticas, valores de importancia, formas de vida de Raunkiaer, índices de diversidad y especies indicadoras para describir atributos comunitarios. La diversidad Beta fue analizada usando el coeficiente de Jaccard. Se discuten también las perturbaciones antropogénicas que actualmente afectan a la vegetación. En total se segregaron 11 comunidades pertenecientes a tres grupos ecológicos: a) comunidades leñosas meso-higromórficas pertenecientes a la cuenca del Baker, conformada principalmente de bosques caducifolios conteniendo valores relativos intermedios de riqueza y diversidad, pero las mayores riquezas de exóticas; b) comunidades leñosas higromórficas pertenecientes al segmento sur de la cuenca del río Baker y a través de toda la cuenca del río Pascua, compuesta de bosques siempreverdes conteniendo los mayores valores de riqueza y diversidad y muy baja riqueza de exóticas, y c) comunidades leñosas achaparradas alto- 
andinas, distribuidas en lugares de alta elevación en ambas cuencas, compuestas de krummholz conteniendo la menor riqueza y diversidad, sin presencia de especies introducidas. El reemplazo de comunidades caduficolias por siempreverdes en sentido norte-sur sucede alrededor de la latitud $48^{\circ} \mathrm{S}$. Perturbaciones antrópicas como la tala de madera por propietarios rurales, sobrepastoreo por ganado doméstico y ampliaciones en los caminos, están provocando invasiones biológicas en los bosques de la cuenca del río Baker, mientras que los bosques de la cuenca del río Pascua, donde no ocurre poblamiento humano, permanecen prístinos.

Palabras clave: Transición biogeográfica, zona templada fría, perturbaciones antrópicas, bosques prístinos, Aysén.

\section{INTRODUCTION}

The Baker and Pascua rivers are located in the Aysén Region in northern Chilean Patagonia. The former is about $175 \mathrm{~km}$ in length, originating at the southern tip of Bertrán Lake and ending in the Baker Channel. The Pascua River, in turn, is 67 $\mathrm{km}$ in length, originating at the northwest side of O'Higgins Lake and ending at the Calén Fjord. Adjacent to both rivers is an extensive $150 \mathrm{~km}$ long basin-strip system, distributed along a steep precipitation gradient with annual precipitation ranging from approximately $350 \mathrm{~mm}$ in the continental areas to $3,000 \mathrm{~mm}$ at the archipelagic locations (Amigo \& Ramírez 1998). These basins are flanked to the northwest by the North Patagonian Ice Fields and to the southwest by the archipelagic zone. The entire area is transected by the Andean mountain range, with elevations ranging from sea level to $1,200 \mathrm{~m}$. The area is thus a tangled corridor where floristic elements transit latitudinally and altitudinally throughout the "Southern Cold Temperate Zone" (Du Rietz 1960, Holdgate 1960) (Fig. 1). The vegetation in this area is diverse and includes Patagonian steppes, shrublands, deciduous forests, perennial forests at low elevations and moorland vegetation above the timberline (e.g. Hueck 1978, Veblen \& Schlegel 1982, Luebert \& Pliscoff 2006). Given the difficult access to some parts of the region and its low human population density ( 0.8 inhabitants per $\left.\mathrm{km}^{2}\right)$, the region contains landscapes in completely pristine conditions (Martínez-Harms \& Gajardo 1998).

The first descriptions of the area's vegetation correspond to phytogeographical studies made at the beginning of the 20th century by Reiche (1934) and Hambleton (1936), who described the forest vegetation and drafted some geographical limits. Hambleton (1936) mentioned the forests dominated by Nothofagus dombeyi (Mirb.) Oerst distributed in the northern area of the Baker basin. Reiche (1934), meanwhile, mentioned the Nothofagus pumilio (Poepp. et Endl.) Krasser forests in the central area of the Baker basin and the presence of steppe-like shrublands in the northeastern area. He described forests in the southern area as being dominated by Nothofagus nitida (Phil.) Krasser and krummholz communities and 'carpet vegetation' above the timberline. Godley (1960) established latitude $48^{\circ} \mathrm{S}$ as the limit where deciduous forests are replaced by perennial forests and subantarctic moorlands.

Although later studies have described and delineated the woodland vegetation of the area (e.g. Fuenzalida \& Pisano 1967, Pisano 1972, Hueck 1978, Veblen \& Schlegel 1982, Luebert \& Pliscoff 2006), none have been able to fully compile its complex structure and diversity, partly due to the difficult access of some of these places. Moreover, some of the authors considered just dominant species, omitting valuable information related to target non-dominant ones. Detailed information can be not only interesting for biogeographers looking to explain biotic patterns, but also useful for managers requiring quantified information to take management decisions (Noss 1990). In this context, this study aimed: 1) to classify and describe the woodland communities along the Baker and Pascua river basins, 2) to compare the floristic diversity among these communities, 3 ) to delineate the distribution of native woodland communities and 4) to describe human disturbances affecting this vegetation.

\section{MATERIALS AND METHODS}

STUDY AREA

The study was carried out in the Baker and Pascua basins, located in the administrative Region of Aysén in northern Chilean Patagonia (Fig. 1). This area $(\sim 150,000$ ha) lies approximately between $47^{\circ} 03^{\prime} \mathrm{S}$ and $48^{\circ} 21^{\prime} \mathrm{S}$ and $73^{\circ} 19^{\prime}$ $\mathrm{W}$ and $72^{\circ} 27^{\prime} \mathrm{W}$. The altitudinal range is from sea level to $\sim 1,200 \mathrm{~m}$. Meteorological data from the study area are not available, but a notable NE-SW climatic gradient can be observed. Annual temperatures recorded at the nearest meteorological stations range from $10^{\circ} \mathrm{C}$ (Chile Chico, $46^{\circ} 36^{\prime} \mathrm{S}-71^{\circ} 43^{\prime} \mathrm{W}$ ) to $7.1^{\circ} \mathrm{C}$ (Puerto Edén, $49^{\circ} 08^{\prime} \mathrm{S}$ $74^{\circ} 25^{\prime} \mathrm{W}$ ), while precipitation ranges from $355 \mathrm{~mm}$ (Chile Chico) to $3,033 \mathrm{~mm}$ (Puerto Edén). These two locations belong to the dry and ultraperhumid bioclimatic belts, respectively, in the temperate zone of Chile (Amigo \& Ramírez 1998). The vegetation in the study area includes arid steppes, xerophylous shrublands and deciduous forests in NE locations, being gradually replaced toward the SW by hygrophilous vegetation such as peatlands, shrublands, and perennial forests (Luebert \& Pliscoff 2006).

FIELD METHODS AND TAXONOMICAL DETERMINATIONS

Between April 2006 and March 2007, four field expeditions were organized in order to cover the entire $\sim 150 \mathrm{~km} \mathrm{NE}$ SW transect in the study area. Sample sites were selected 
according to a stratified design using aerial photographs and were accessed by means of horses, vehicles, boats and helicopters because of the difficulty of the terrain.

In each site a $500 \mathrm{~m}^{2}$ phytosociological relevé (Mueller-Dombois \& Ellenberg 1974) was delimited to record all vascular plants and to estimate the percentage of abundances of each. Topographical features such as elevation, slope inclination, slope aspect and GPS location were also recorded. Voucher specimens were collected and determined using taxonomical literature (Cabrera 1949, Muñoz-Schick 1980, Moore 1982, Matthei 1995, Ruiz 2001, Landrum 2003, Rodríguez \& Quezada 2003, Marticorena 2006). Nomenclature follows Henríquez et al. (1995) and Rodríguez et al. (2008).

\section{DATA ANALYSIS}

We constructed a relevé-by-species abundance matrix containing a total of 256 relevés and 201 species. Species abundance data were transformed by using the logarithmic transformation $(\log (\mathrm{x}+1))$ to get an approximation close to normal and to stabilize the variance (McCune \& Grace 2002), as required for multivariate methods. In order to detect plant communities, the relevé-by-species abundance matrix was classified by performing hierarchical agglomerative clustering using Ward's minimum variance criterion (Euclidean distance) to minimize the increase in within-group variance (Hammer et al. 2001). Sites belonging to a particular cluster-group (i.e. community) were pooled and the new community-by-species matrix was ordinated using principal component analysis (PCA) (Euclidean distance) to examine the structure of nodal communities. From each community-by-species matrix the structural and compositional attributes of vegetation biodiversity were extracted (Noss 1990), i.e. mean species richness, cumulative abundances, importance values (Wikum \& Shanholtzer 1978), diversity indices (Shannon and Berger-Parker, Moreno 2001), Raunkiaer plant life-forms (Mueller-Dombois \& Ellenberg 1974) and exotic-native species ratio (Noss 1990). Indicator species analysis (Dufrêne \& Legendre 1997) was performed to assess fidelity of particular species to each community as diagnostic species. In order to compare diversity between communities, a beta diversity comparison matrix using the Jaccard coefficient (Lapin \& Barnes 1995) was performed from the pooled database. Finally the patterns of biological invasions were explored by evaluating correlation between elevation of sites, distance to roads and number of exotic plant species. Structural and compositional attributes of communities, cluster analysis, PCA and correlations were performed using the PAST statistical package version 1.91 (Hammer et al. 2001). ISA was performed using the labdsv indval Package for R statistical software.

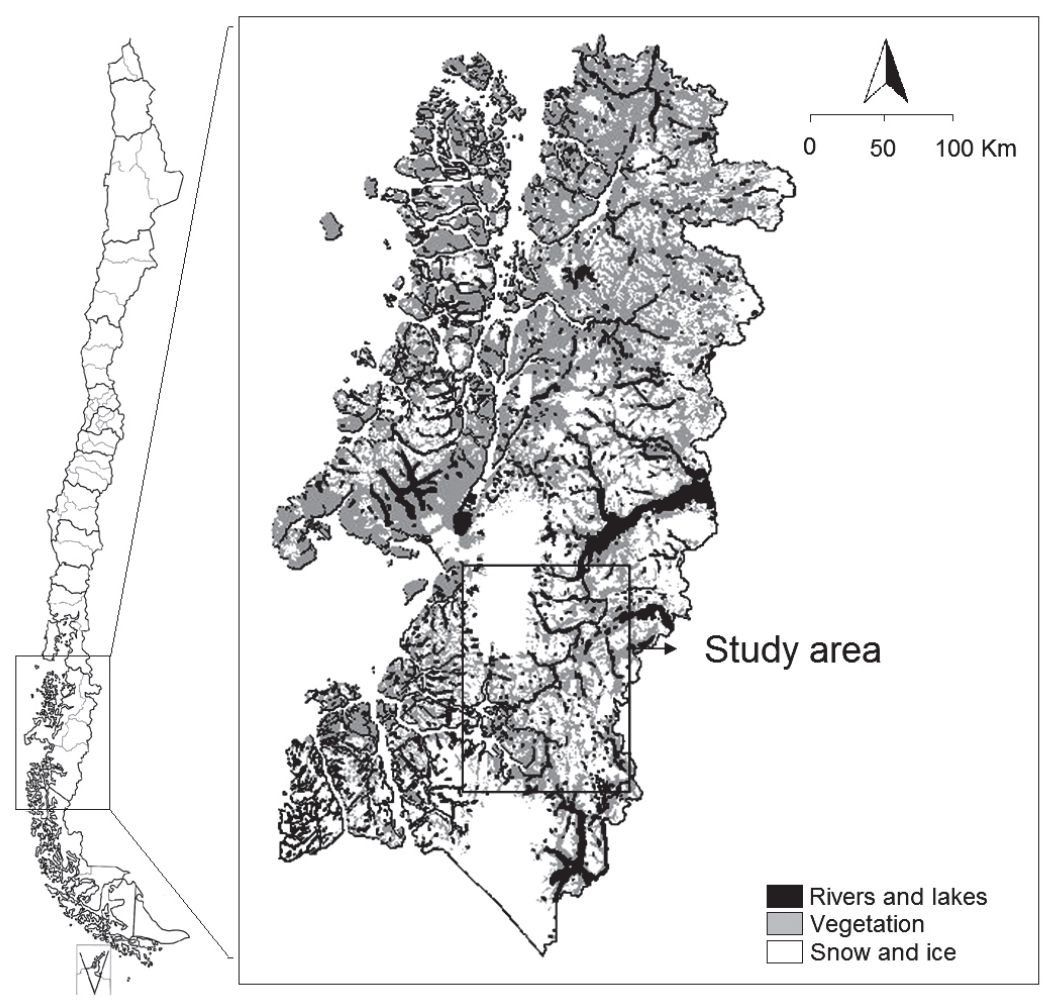

Figure 1. Map of Aysén, northern Chilean Patagonia, showing the study area.

Figura 1. Mapa de Aysén, Norte de Patagonia Chilena, mostrando el área de estudio. 


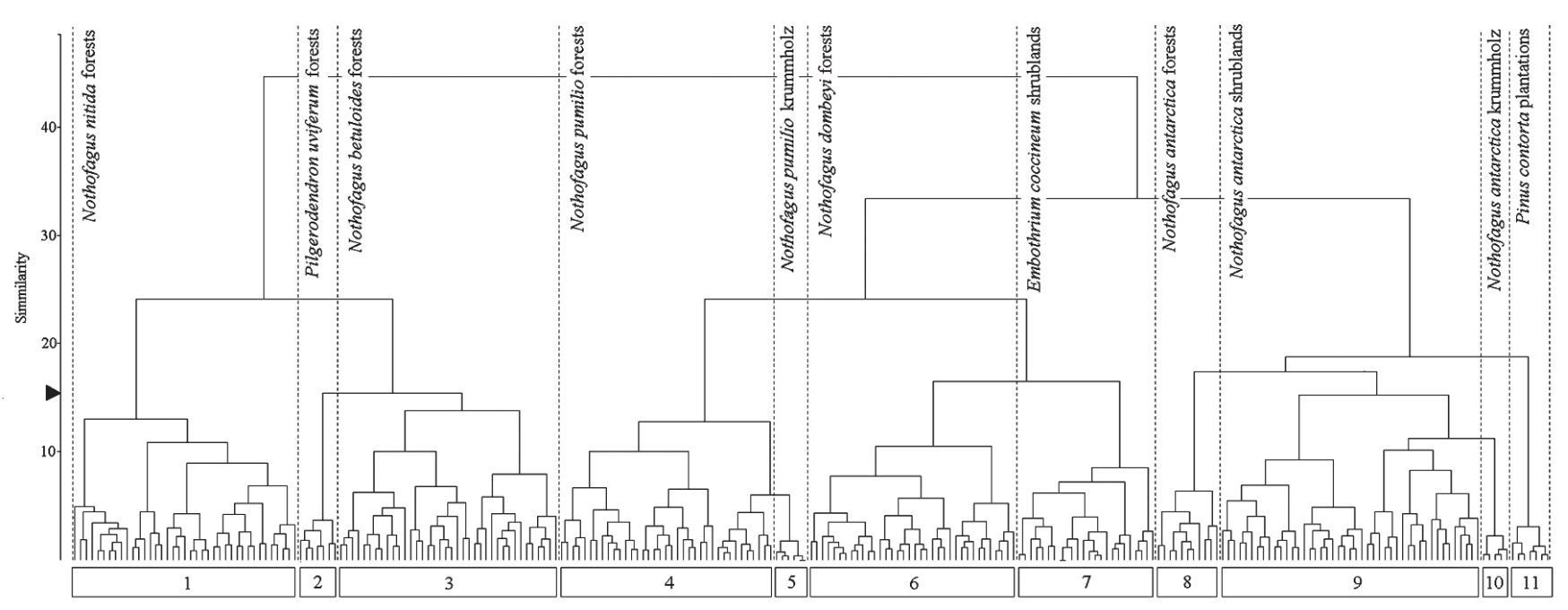

FiguRE 2. Dendrogram showing floristic relationships among the communities segregated in the present study. The arrow on the $y$-axis indicates the segregation point. Communities 5 and 10 were arbitrarily segregated (see results section).

Figura 2. Dendrograma mostrando las relaciones florísticas entre las comunidades segregadas en el presente estudio. La flecha en el eje $y$ muestra el punto de segregación. Las comunidades 5 y 10 fueron segregadas arbitrariamente (ver la sección de resultados).

\section{RESULTS}

ClASSIFICATION, ORDINATION AND DESCRIPTION OF COMMUNITIES Nine woodland communities were classified after clustering (Fig. 2), but 2 sub-groups, krummholz dominated by Nothofagus pumilio (5 relevés) and krummholz dominated by Nothofagus antarctica (G.Forst.) Oerst. (5 relevés), were arbitrarily reassigned as communities based on their habitat features (lower canopy heights), lower number of species and site topography (high elevation sites, steep slopes).

The ordination diagram (Fig. 3) showed the nodal communities distributed in 3 groups along the two principal components, explaining $53.8 \%$ of the variance. These components can be hypothesized as environmental factors affecting the distribution of plant communities. We thus hypothesized that component 1 (x-axis) was temperature and component 2 (y-axis) was precipitation. The first group contained 3 communities distributed in colder and more humid places and included forests dominated by Nothofagus betuloides (Mirbel) Oersted, forests dominated by Nothofagus nitida and forests dominated by Pilgerodendron uviferum (D.Don) Florin. The second group contained 5 communities distributed in warmer places with intermediate levels of precipitation and included Nothofagus antarctica forests, Embothrium coccineum shrublands, Nothofagus antarctica shrublands, Nothofagus dombeyi forests and Nothofagus pumilio forests. The third group of communities can be considered to be distributed in dry and cold places and included krummholz dominated by Nothofagus antarctica and krummholz dominated by Nothofagus pumilio. A brief description of the plant communities is provided below, based on dominant species, importance values (IV), diagnostic species identified by indicator species analysis (ISV) (Annex 1), plant life-forms (Fig. 4), and cumulative richness of native and exotic species. Communities were named according to the dominant species, but a phytosociological name from the literature was also provided:

1) Nothofagus nitida forests (Luzuriago polyphyllaeNothofagetum nitidae). Evergreen and multi-layered forests located mainly in lowland and flat areas $(0-400 \mathrm{~m})$ close to river courses and lakes. Trees reach up to a height of $30 \mathrm{~m}$. The vegetation structure is complex, dominated in the upper layer by Nothofagus nitida (IV 32.2) but co-dominated by other phanerophytes like Podocarpus nubigena Lindl. (IV 18.7), Drimys winteri J.R.Forst. et G.Forst. (IV 16.5) and Desfontainia fulgens D.Don (IV 3.7), among others. There is a notable presence of plants growing as epiphytes, including Hymenophyllum krauseanum Phil. (IV 18.5), Philesia magellanica J.F.Gmel. (IV 5.3) and Mitraria coccinea Cav. (IV 5.0). The shrub layer is also rich, containing microphanerophytes like Pseudopanax laetevirens (Gay) Franchet (IV 10.5) and Chusquea culeou E. Desv. (IV 4.0). On the ground are hemicryptophytes like Blechnum pennamarina (Poir.) Kuhn (IV 9.3), Blechnum magellanicum (Desv.) Mett. (IV 7.8) and Rubus geoides Sm. (IV 3.9), among many other species. Exotic elements are not important but include some species like Holcus lanatus L.(IV 0.6), Prunella vulgaris L. (IV 0.6) and Trifolium repens L. (IV 0.5), among others. Diagnostic species with the greatest ISA values were Nothofagus nitida (ISA 1.0), Hymenophyllum krauseanum (ISV 0.7) and Griselinia rusciflora (Clos) Ball. (ISV 0.56). 
No human disturbance affected these stands, although a few exotic species were detected. We recorded 67 species belonging to these stands, 7 of them exotic. These forests were distributed in the central and southern section of the Baker basin and in the northern section of the Pascua basin.

\section{2) Pilgerodendron uviferum forests (Empetro-} Pilgerodendronetum uviferae). Evergreen resinous multilayered forests associated with flat and inundated areas (0 - $400 \mathrm{~m}$ ) where extensive cover of the moss Sphagnum magellanicum Brid on the ground was observed. Dominant trees reached up to $6 \mathrm{~m}$ in height. Pilgerodendron uviferum dominated in cover and frequency (IV 30.5) at the upper layer, and Empetrum rubrum Vahl ex Willd. (IV 26.4) co-dominated at the ground layer. Other important species were Gaultheria mucronata (L.f.) Hook. et Arn. (IV 17.7), the epiphyte Philesia magellanica (IV 12.4) and the phanerophyte Nothofagus antarctica (IV 8.8). Diagnostic species with the greatest ISV values included Pilgerodendron uviferum (ISV 0.79), Oreobolus obtusangulus Gaudich. (ISV 0.57) and Empetrum rubrum (ISV 0.49). Large areas of these forests were burned during colonial times and remained standing, some of them providing seed trees. We recorded 36 species in these stands, all of them native. The stands were distributed in the southern segment of the Baker basin.

3) Nothofagus betuloides forests (Nothofagetum betuloidis). Evergreen forests associated with gentle slopes and mountainous areas from sea level to $\sim 600$ $\mathrm{m}$ elevation. Vegetation structure was multi-layered, dominated by Nothofagus betuloides (IV 30.9) in the upper tree layer, but co-dominated by other trees like Desfontainia fulgens (IV 10.7), Podocarpus nubigena (IV 10.4) and Drimys winteri (IV 9.5). The presence of many epiphytes was detected on the trees, including Philesia magellanica (IV 14.6) and ferns like Serpyllopsis caespitosa (Gaudich.) C.Chr. (IV 6.0), Hymenophyllum tortuosum Hook. et Grev. (IV 2.2) and Hymenophyllum pectinatum Cav. (IV 1.1). The shrub layer was also rich in species and included many microphanerophytes like Gaultheria mucronata (IV 17.2), Berberis ilicifolia L.f. (IV 8.0) and Lebetanthus myrsinites (Lam.) Dusen (IV 7.8), among others. Ground vegetation was also rich in species and includes Blechnum penna-marina (IV 5.7), Sticherus quadripartitus (Poir.) Ching (IV 5.2) and Blechnum magellanicum (IV 4.7). Diagnostic species with the greatest ISV values included Nothofagus

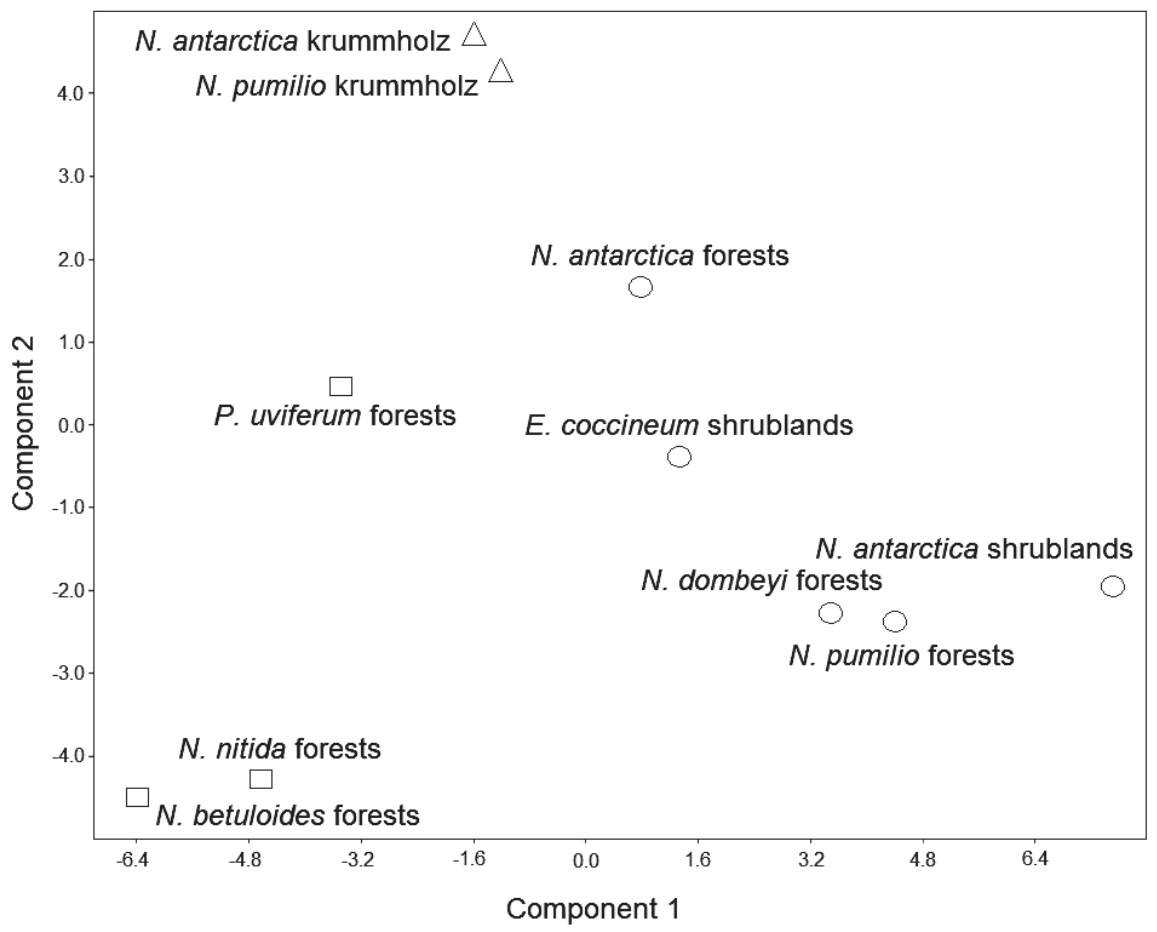

FigURE 3. Diagram of principal component analysis (PCA) summarizing ordination of native woodland communities in the Baker and Pascua basins. The components explain $53.8 \%$ of the variance. Symbols: $O=$ meso-hygromorphic woodlands, mostly deciduous woodlands, $\square=$ hygromorphic woodlands, perennial woodlands, and $\Delta=$ high-Andean dwarf woodlands, krummholz communities.

Figura 3. Diagrama basado en el análisis de componentes principales (PCA) resumiendo la ordenación de las comunidades leñosas nativas en las cuencas del Baker y del Pascua. Los componentes explican el 53,8\% de la varianza. Símbolos: $\bigcirc=$ comunidades leñosas mesohigromórficas, principalmente conformadas por bosques caducifolios, $\square=$ comunidades leñosas higromórficas, conformadas por bosques perennes y $\Delta$ = matorrales achaparrados alto-andinos, comunidades del tipo krummholz. 
Species number

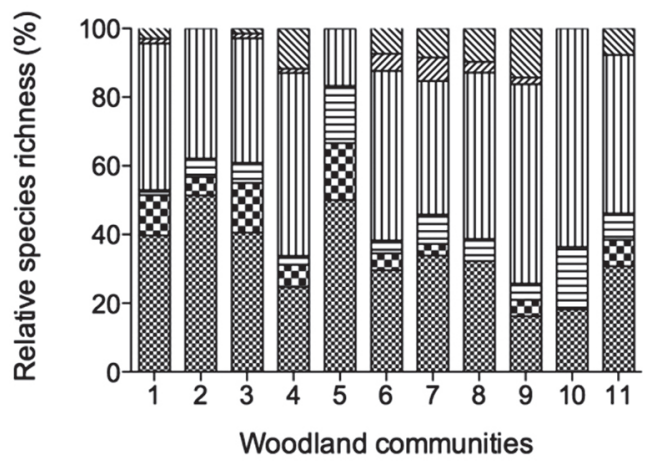

Species abundances

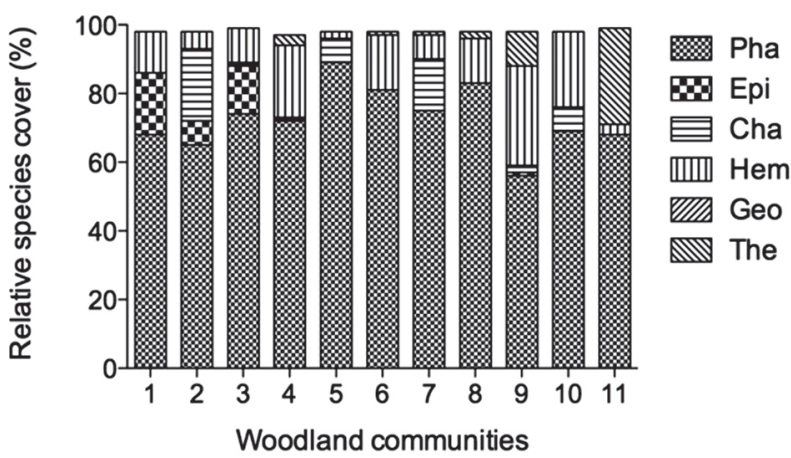

FIGURE 4. Raunkiaer life-form spectrum of different woodland communities in the Baker and Pascua basins according to species number (relative richness) and species abundances (relative cover) of species. Raunkiaer plant life-forms: Pha= Phanerophyte, Epi= Epiphytes, $\mathrm{Cha}=$ Chamaephyte, Hem= Hemicryptophyte, $\mathrm{Geo}=$ Geophyte, The= Therophyte. Name of communities: 1. Nothofagus nitida forests, 2. Pilgerodendron uviferum forests, 3. Nothofagus betuloides forests, 4. Nothofagus pumilio forests, 5. Nothofagus pumilio krummholz, 6. Nothofagus dombeyi forests, 7. Embothrium coccineum shrublands, 8. Nothofagus antarctica forests, 9. Nothofagus antarctica shrublands, 10. Nothofagus antarctica krummholz, 11. Pinus contorta plantations.

Figura 4. Espectros biológicos basados en las formas de vida de Raunkiaer para las diferentes comunidades leñosas en las cuencas de los ríos Baker y Pascua, de acuerdo al número de especies (riqueza relativa) y abundancia de especies (cobertura relativa). Formas de vida de Raunkiaer: $\mathrm{Pha}=$ fanerófitos, Epi $=$ epífitos, $\mathrm{Cha}=$ caméfitos, Hem= hemicriptófitos, Geo= geófitos, The $=$ terófitos. Nombre de las comunidades: 1. Bosques de Nothofagus nitida, 2. Bosques de Pilgerodendron uviferum, 3. Bosques de Nothofagus betuloides, 4. Bosques de Nothofagus pumilio, 5. Krummholz de Nothofagus pumilio, 6. Bosques de Nothofagus dombeyi, 7. Matorrales de Embothrium coccineum, 8. Bosques de Nothofagus antarctica, 9. Matorrales de Nothofagus antarctica, 10. Krummholz de Nothofagus antarctica, 11. Plantación de Pinus contorta.

betuloides (ISV 0.7), Serpyllopsis caespitosa (ISV 0.5) and Desfontainia fulgens (ISV 0.38), among others. No human disturbances were detected in these stands. We recorded a total of 68 species, all of them native. These stands were detected in the southern section of Baker and Pascua basins.

4) Nothofagus pumilio forests (Mayteno-Nothofagetum pumilionis). Deciduous forests associated with gentle slopes from $\sim 100 \mathrm{~m}$ to $\sim 1,000 \mathrm{~m}$ in elevation. Dominant trees reached up to $30 \mathrm{~m}$ in height and the vegetation structure was 3-layered, with Nothofagus pumilio (IV 52.2) dominating at the upper layer. Gaultheria mucronata (IV 17.7), Maytenus disticha (Hook.f.) Urban (IV 7.5), Berberis microphylla Hort ex. K.Koch (IV 6.3) and Berberis darwinii Hook. (IV 6.3) were the most important microphanerophytes in the shrub layer. The ground layer was rich in species, with many hemicryptophytes like Blechnum penna-marina (IV 7.8), Fragaria chiloensis (L.) Duch. (IV 7.2) and Adenocaulon chilense Poepp. ex Less. (IV 6.7) as natives, and Trifolium repens L. (IV 4.1) and Taraxacum officinale (L.) Weber (IV 3.2) as the most important exotics. Diagnostic species included Nothofagus pumilio (ISV 0.55), Viola maculata Cav. (ISV 0.49), Maytenus disticha (ISV 0.43), Adenocaulon chilense (ISV 0.25) and the orchid Codonorchis lesonii (Brongn.) Lindl. (ISV 0.18). The stands were affected by human disturbances like the use of wood for fuel and overgrazing by livestock. A consequent modification of the structure (e.g. reduction in canopy cover) and floristic composition of these forests (particularly the introduction of exotic species) was observed. We recorded a total of 79 species in these stands, 19 of them exotic. The distribution of these forests was restricted to the Baker basin.

5) Nothofagus pumilio krummholz (EmpetroNothofagetum pumiliae). Deciduous and dense shrubland reaching up to $2 \mathrm{~m}$ in height, poor in species and associated with high elevation areas at the timberline from $\sim 1,000$ to $1,200 \mathrm{~m}$. The vegetation structure was reduced to only 2 strata, with the upper layer dominated by $N$. pumilio (IV 116.6) and co-dominated by Escallonia alpina Poepp. \& Endl. (IV 4.9). The floristic composition was poor, with Empetrum rubrum (IV 31.7) and Gaultheria pumila (L.f.) D.J.Middleton (IV 20.3) as chamaephytes and some hemicryptophytes like Rubus geoides (IV 21.6) and Luzula racemosa (IV 4.9). Diagnostic species included Gaultheria pumila (ISV 0.34) and Rubus geoides (ISV 0.29). Stands were pristine and not affected by human disturbances due to their difficult accessibility. We recorded a total of 6 species, all of them native. The distribution of these stands was restricted to the Baker basin. 
6) Nothofagus dombeyi forests (ChrysosplenioNothofagetum dombeyi). Monospecific perennial forests located in low elevation areas near water bodies from sea level to $\sim 500 \mathrm{~m}$. Trees reached up to $40 \mathrm{~m}$ in height. The vegetation structure was 3-layered, with $N$. dombeyi (IV 64.8) as the dominant species and Gaultheria mucronata (IV 15.0), Berberis microphylla (IV 7.2), Embothrium coccineum J.R.Forst. et G.Forst (IV 6.6), and Berberis darwinii (IV 6.4) as important microphanerophytes in the shrub layer. The ground vegetation was rich in species, with Blechnum penna-marina (IV 12.6), Adenocaulon chilense (IV 6.5) and Acaena ovalifolia Ruiz \& Pav. (IV 6.0) being the most important native hemicryptophytes. Some exotics included Taraxacum officinale (IV 3.2), Holcus lanatus (IV 2.0) and Hypochaeris radicata L. (IV 1.4), among others. Diagnostic species included Nothofagus dombeyi (ISV 0.89), Ribes magellanicum Poir. (ISV 0.18) and Viola reichei Skottsb. (ISV 0.16). Stands are affected by logging due to the use of wood as fuel by the rural landowners. Overgrazing of livestock was also observed in these stands, with evident browsing of shrubs and regenerating trees. We recorded a total of 81 species, 17 of them exotic. The distribution of these stands was restricted to the Baker basin.

7) Embothrium coccineum shrublands (EmbothrioPernettietum mucronatae). Deciduous tree shrublands colonizing gentle slopes fluctuating from sea level to 900 $\mathrm{m}$. The vegetation structure was 3-layered, with Embothrium coccineum as the dominant phanerophyte but which did not form a continuous canopy (IV 33.3). Gaultheria mucronata was the dominant microphanerophyte at the shrub layer (IV 44.0). Other phanerophyte species were Escallonia rosea Griseb. (8.7), Berberis microphylla (IV 7.0) and Nothofagus antarctica (IV 5.3). The ground layer was rich in species, containing some chamaephytes like Baccharis magellanica (Lam.) Pers. (IV 14.4) and Empetrum rubrum (IV 12.0), and hemicryptophytes like Festuca pyrogea Speg. (IV 5.0), Blechnum penna-marina (IV 5.0) and Fragaria chiloensis (IV 4.4). Important exotics were Hypochaeris radicata (IV 2.5) and Rumex acetosella L. (IV 2.1). Diagnostic species included Embothrium coccineum (ISV 0.6), Escallonia rosea (ISV 0.51) and Baccharis magellanica (ISV 0.49) as phanerophytes. Lycopodium paniculatum Desv. (ISV 0.39) and Gavilea odoratissima Poepp. (ISV 0.34) were included as hemicryptophyte and geophyte diagnostic species, respectively. These shrublands were affected to a small degree by human disturbances derived from livestock production. We recorded a total of 59 species, 8 of them exotic. The distribution of these shrublands was restricted to the Baker basin, especially in the southern section.

8) Nothofagus antarctica forests (Chusqueo-Nothofagetum antarcticae). Deciduous forests associated with areas of depressions in the relief, close to river meanders from sea level to $\sim 80 \mathrm{~m}$. The structure was 3-layered, with Nothofagus antarctica (IV 47.0) as the dominant species, reaching up to $15 \mathrm{~m}$ in height. Chusquea culeou (IV 32.4) and Embothrium coccineum (IV 5.8) were the co-dominant species in the upper and shrub layer. Microphanerophytes in the shrub layer included Escallonia virgata (IV 13.8), Gaultheria mucronata (IV 9.2) and Berberis microphylla (IV 8.2). The ground vegetation was rich in species, containing many hemicryptophytes like Blechnum penna-marina (IV 16.6), Acaena ovalifolia (IV 7.3), and Rubus geoides (IV 4.2). Exotics included Prunella vulgaris (IV 4.4), Taraxacum officinale (IV 4.2) and Trifolium repens (IV 3.4). Diagnostic species were Chusquea culeou (ISA 0.76), Escallonia virgata (ISA 0.40) and Blechnum penna-marina (ISA 0.20), among others. In these forests we recorded a total of 31 species, 6 of them exotic. The distribution of these stands was restricted to the southern section of the Baker basin.

9) Nothofagus antarctica shrublands (Anemone polyphyllae-Nothofagetum antarcticae). Deciduous tree shrublands reaching up to $8 \mathrm{~m}$ in height, located in flat areas from sea level to $\sim 500 \mathrm{~m}$. The structure was 3-layered with Nothofagus antarctica dominating the upper layer (IV 47.2). Other phanerophytes such as Berberis microphylla (IV 6.2), Discaria chacaye (IV 4.8), and Ribes cucculatum (IV 3.5) were present but had values of little importance. The understory was rich in species, containing many natives like Festuca pyrogea (IV 8.7), Blechnum penna-marina (IV 8.0), Anemone multifida (IV 7.6) and Fragaria chiloensis (IV 6.6), and many exotics like Taraxacum officinale (IV 6.0), Holcus lanatus (IV 4.1), Trifolium repens (IV 3.6) and Achillea millefolium (IV 3.5), among others. The diagnostic species included Anemone multifida (ISV 0.40) and Discaria chacaye (ISV 0.29) as natives, and some exotics like Achillea millefolium (ISV 0.26), Cerastium arvense (0.16) and Carduus nutans (ISV 0.13), among others. Cattle heavily affected these shrublands because the ground plant cover was used as forage. Pinus contorta populations have also invaded some stands. In total we recorded 107 species in these stands, 38 of them exotic. The distribution of these forests occurred along the entire Baker basin.

10) Nothofagus antarctica krummholz (Senecio acanthifoliae-Nothofagetum antarcticae). Deciduous dwarf shrublands reaching up to a height of $1 \mathrm{~m}$, poor in species and located in highlands from 600 to $900 \mathrm{~m}$. The structure was 2layered and dominated by Nothofagus antarctica (IV 85.9) in the upper layer as the only phanerophyte. The understory cover was dominated by Gunnera magellanica (IV 28.1) and Senecio acanthifolius (IV 23.3) as hemicryptophytes, and Bolax caespitosa (IV 17.5) and Empetrum rubrum (IV 10.4) as chamaephytes. The diagnostic species included Senecio acanthifolius (ISV 0.92), Gunnera magellanica (ISV 0.62) and Bolax caespitosa (ISV 0.60), among others. No human 
disturbances were detected in these stands. In total we recorded 11 species, all of them native. These stands were distributed along the entire Pascua basin.

11) Pinus contorta plantations. Exotic monoculture located near the village of Cochrane, between 200 - 300 m. The structure was 3-layered with Pinus contorta (IV 67.2) having the major importance value. Nothofagus antarctica (IV 26.3) was also an important phanerophyte. Microphanerophytes in the shrub layer included Berberis microphylla (IV 7.3) and Gaultheria mucronata (IV 2.4). The ground vegetation was poor in species and included some natives like Nertera granadensis (IV 13.5), Acaena ovalifolia (IV 7.3) and Osmorhiza chilensis (IV 4.7), and some exotics like Agrostis stolonifera (IV 44,3), Taraxacum officinale (IV 12.2) and Trifolium repens (IV 2.4). Diagnostic species were Pinus contorta (ISV 1.0), Agrostis stolonifera (ISV 0.87) and Nertera granadensis (ISV 0.51). Some Pinus contorta individuals were growing outside of plantations and invading native communities. In total we recorded 13 species, 4 of them exotic. The distribution of these stands is restricted to close to the village of Cochrane in the Baker basin.

\section{COMMUNITY COMPARISONS AND DISTURBANCE PATTERNS}

Mean cover and richness of native and exotic plant species as well as diversity indices (Shannon and Beger-
Parker) are presented in Table I. Forest communities dominated by Nothofagus nitida, Pilgerodendron uviferum and Nothofagus betuloides have the highest richness as well as cover and Shannon diversity values, indicating relatively equitable participation in cover for many species. In these communities, exotic elements are virtually absent, with only Nothofagus nitida forests having low values of exotics. On the other hand, communities containing the lowest values of richness are Nothofagus pumilio krummholz, Nothofagus antarctica krummholz and the Pinus contorta plantations. These communities also contain the lowest Shannon index values but have the highest Berger-Parker index values, indicating the higher cover of the dominant woods. The communities most invaded by exotics are Nothofagus antarctica shrublands, Nothofagus pumilio forests and Pinus contorta plantations, while 4 communities have no exotics (Pilgerodendron uviferum forests, Nothofagus betuloides forests, Nothofagus antarctica krummholz and Nothofagus pumilio krummholz).

Similarities among communities based on the Jaccard coefficient vary from 0.49 between Nothofagus dombeyi forests and Embothrium coccineum shrublands (the highest value) to no similarity (value 0 for the index) between Nothofagus pumilio krummholz and Pinus contorta plantations, revealing that each community has its own identity in terms of species composition (Table II).

TABLE I. Diversity structure of woody communities in the Baker and Pascua basins.

TABLA I. Diversidad estructural de las comunidades leñosas en las cuencas de los ríos Baker y Pascua.

\begin{tabular}{|c|c|c|c|c|c|c|}
\hline WOODLAND COMMUNITY & $\begin{array}{l}\text { NATIVE } \\
\text { RICHNESS }\end{array}$ & $\begin{array}{l}\text { EXоTIC } \\
\text { RICHNESS }\end{array}$ & $\begin{array}{l}\text { Native } \\
\text { COVERS }\end{array}$ & $\begin{array}{l}\text { EXOTIC } \\
\text { COVERS }\end{array}$ & $\begin{array}{l}\text { SHANNON } \\
\text { INDEX }\end{array}$ & $\begin{array}{l}\text { BERGER PARKER } \\
\text { INDEX }\end{array}$ \\
\hline Nothofagus nitida forests & $14.8 \pm 3.4$ & $0.4 \pm 0.8$ & $140.5 \pm 31.5$ & $1.0 \pm 4.2$ & $1.878 \pm 0.311$ & $0.366 \pm 0.122$ \\
\hline Pilgerodendron uviferum forests & $20.4 \pm 3.2$ & - & $173.1 \pm 20.6$ & - & $2.175 \pm 0.148$ & $0.305 \pm 0.058$ \\
\hline Nothofagus betuloides forests & $16.2 \pm 3.9$ & - & $149.7 \pm 44.5$ & - & $1.995 \pm 0.340$ & $0.313 \pm 0.121$ \\
\hline Nothofagus pumilio forests & $13.8 \pm 3.1$ & $2.2 \pm 2.0$ & $123.7 \pm 34.4$ & $7.3 \pm 11.4$ & $1.636 \pm 0.348$ & $0.485 \pm 0.125$ \\
\hline Nothofagus pumilio krummholz & $3.5 \pm 1.4$ & - & $110.0 \pm 14.5$ & - & $0.371 \pm 0.329$ & $0.891 \pm 0.104$ \\
\hline Nothofagus dombeyi forests & $11.6 \pm 3.5$ & $1.6 \pm 2.5$ & $127.0 \pm 34.0$ & $4.0 \pm 8.0$ & $1.276 \pm 0.379$ & $0.601 \pm 0.168$ \\
\hline Embothrium coccineum shrublands & $12.3 \pm 2.5$ & $0.8 \pm 0.9$ & $132.5 \pm 49.1$ & $0.8 \pm 0.9$ & $1.609 \pm 0.189$ & $0.429 \pm 0.110$ \\
\hline Nothofagus antarctica forests & $8.9 \pm 2.4$ & $1.3 \pm 1.6$ & $138.6 \pm 37.3$ & $7.4 \pm 11.4$ & $1.512 \pm 0.197$ & $0.411 \pm 0.079$ \\
\hline Nothofagus antarctica shrublands & $12.2 \pm 2.8$ & $4.5 \pm 2.5$ & $113.4 \pm 42.6$ & $14.5 \pm 19.7$ & $1.716 \pm 0.311$ & $0.440 \pm 0.130$ \\
\hline Nothofagus antarctica krummholz & $6.0 \pm 2.1$ & - & $136.6 \pm 33.7$ & - & $0.795 \pm 0.371$ & $0.728 \pm 0.185$ \\
\hline Pinus contorta plantations & $3.3 \pm 1.6$ & $2.9 \pm 0.7$ & $26.6 \pm 22.6$ & $103.9 \pm 41.9$ & $0.879 \pm 0.429$ & $0.610 \pm 0.239$ \\
\hline
\end{tabular}


TABLE II. Jaccard index values for all pairs of woodland communities.

TABLA II. Valores para el índice de Jaccard para todos los pares de comunidades comparados.

\begin{tabular}{|c|c|c|c|c|c|c|c|c|c|c|c|}
\hline COMMUNITY TYPE & 1 & 2 & 3 & 4 & 5 & 6 & 7 & 8 & 9 & 10 & 11 \\
\hline 1. Nothofagus nitida forests & 1.00 & 0.24 & 0.38 & 0.26 & 0.03 & 0.34 & 0.29 & 0.32 & 0.21 & 0.04 & 0.13 \\
\hline 2. Pilgerodendron uviferum forests & & 1.00 & 0.37 & 0.15 & 0.05 & 0.14 & 0.22 & 0.18 & 0.10 & 0.07 & 0.07 \\
\hline 3. Nothofagus betuloides forests & & & 1.00 & 0.24 & 0.06 & 0.18 & 0.23 & 0.15 & 0.15 & 0.08 & 0.05 \\
\hline 4. Nothofagus pumilio forests & & & & 1.00 & 0.06 & 0.45 & 0.35 & 0.29 & 0.43 & 0.05 & 0.14 \\
\hline 5. Nothofagus pumilio krummholz & & & & & 1.00 & 0.04 & 0.02 & 0.03 & 0.05 & 0.13 & 0.00 \\
\hline 6. Nothofagus dombeyi forests & & & & & & 1.00 & 0.49 & 0.29 & 0.39 & 0.02 & 0.11 \\
\hline 7. Embothrium coccineum shrublands & & & & & & & 1.00 & 0.29 & 0.29 & 0.04 & 0.09 \\
\hline 8. Nothofagus antarctica forests & & & & & & & & 1.00 & 0.25 & 0.05 & 0.26 \\
\hline 9. Nothofagus antarctica shrublands & & & & & & & & & 1.00 & 0.04 & 0.10 \\
\hline 10. Nothofagus antarctica krummholz & & & & & & & & & & 1.00 & 0.04 \\
\hline 11. Pinus contorta plantations & & & & & & & & & & & 1.00 \\
\hline
\end{tabular}
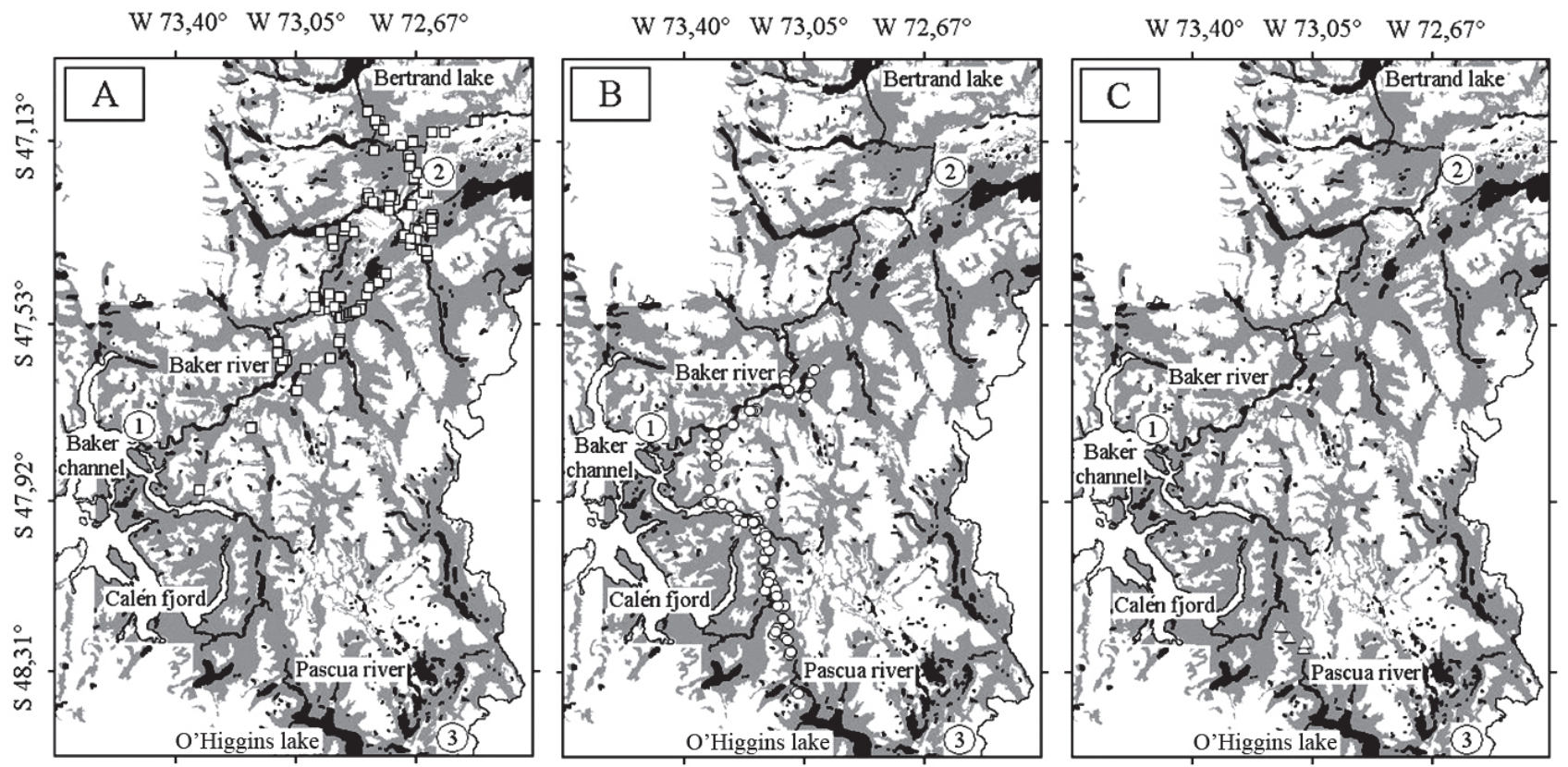

Figure 5. Map showing the location of phytosociological relevés in the study area: A) relevés belonging to the meso-hygromorphic woodlands, B) relevés belonging to the hygromorphic woodlands and C) relevés belonging to the high-Andean dwarf woodlands. The numbers indicates the towns close to the basins: 1) Caleta Tortel, 2) Cochrane and 3) the village of O'Higgins.

Figura 5. Mapa mostrando la locación de los relevamientos fitosociológicos en el área de estudio: A) relevamientos pertenecientes e las comunidades leñosas meso-higromórficas, B) relevamientos correspondientes a las comunidades leñosas higromórficas y C) relevamientos correspondientes a los matorrales achaparrados alto-andinos. Los números indican los poblados cercanos a las cuencas: 1) Caleta Tortel, 2) Cochrane y 3) Villa O’Higgins. 
A weak correlation between the number of exotics and the distance to roads was observed $(r=-0.213, p=0.001)$ when all relevés $(n=256)$ were evaluated, indicating that roads have little influence as corridors for exotics. Moreover, these correlations are stronger for some communities when they are analyzed independently, indicating specific responses of communities. Thus, the presence of exotics in Nothofagus pumilio forests is strongly correlated with the elevation of the relevés ( $r=$ $-0.494, p=0.002)$ as well as with the distance to roads ( $r=-0.493, p=0.002)$. Similarly, Nothofagus antarctica shrublands also showed significant correlations between elevation of relevés and number of exotics $(r=-0.454$, $p=0.001$, but exotic presence in this community is not significantly influenced by distance to roads.

\section{DISCUSSION}

COMPOSITION AND DISTRIBUTION OF WOODLAND COMMUNITIES The native vegetation in the study area can be classified into 3 groups (Fig. 4): 1) Meso-hygromorphic woodlands, mostly composed of deciduous woodlands with continental influence, 2) Hygromorphic woodlands, consisting of evergreen woodlands with oceanic influence, and 3) High-Andean dwarf woodlands, consisting of krummholz communities.

1) Meso-hygromorphic woodlands (Figure 5A), consisting mainly of deciduous woodlands in warmer and drier places in the NE section of the study area with sub-hyperoceanic influence (Luebert \& Pliscoff 2006), typically within the Baker basin. The communities included here are $N$. antarctica forests, E. coccineum tree shrublands, $N$. dombeyi forests, $N$. pumilio forests and $N$. antarctica tree shrublands. The vegetation in the Baker basin is more heterogeneous, consisting mainly of a mosaic of vegetation formations with greater or lesser degrees of disturbance due to livestock activities, but its structure is less complex and contains a smaller number of species as well as lower diversity. $N$. dombeyi forests were described in the study area by Hambleton (1936), who located these stands in the northern portion of the Baker basin. Other communities from this belt, like $N$. pumilio forests and $N$. antarctica forests, were also mentioned for this basin from a phytogeographical point of view (Reiche 1934), but a numerical comparison is hard to establish here. In this mesohygromorphic woodland group, $N$. dombeyi forests are the only perennial community, which, as a typical component of the northern-Valdivian phytogeographical region (Ramírez et al. 1997, Amigo \& Ramírez 1998), reaches its southern distribution range in the study area. The southern limit of this vegetation as a whole is the so-called 'Cold Temperate Zone' (Godley 1960, Holdgate 1960, Skottsberg 1960), and was established at $48^{\circ} \mathrm{S}$ by Godley (1960). Our southernmost record for this belt reached $47.9^{\circ} \mathrm{S}$.
2) Hygromorphic woodlands (Fig. 5B), consisting of perennial woodlands in colder and more humid places in the SW section of the study area, with euhyperoceanic influence (Luebert \& Pliscoff 2006), present at the southern section of the Baker river basin and along the Pascua basin. The communities included here are forests dominated by $N$. nitida, forests dominated by Pilgerodendron uviferum and forests dominated by $N$. betuloides. The vegetation is more homogeneous than the meso-hygromorphic woodlands, but its structure is complex, containing higher richness and diversity than the drier belt (Amigo et al. 2004). Forests dominated by $N$. betuloides were described by Hambleton (1936), who extended their distribution to the archipelagic areas, probably confusing the species with $N$. nitida. The community dominated by $N$. nitida, however, was correctly mentioned by Reiche (1934). It is situated in areas near the mouth of the Baker River. $N$. nitida stands reach their southern distribution limit at $49^{\circ} \mathrm{S}$ along the coastline, while $N$. betuloides and $P$. uviferum stands reach the antiboreal macrobioclimatic belt beyond $52^{\circ} \mathrm{S}$ (Oberdorfer 1960, Amigo \& Ramírez 1998, Luebert \& Pliscoff 2006). Pisano (1972), however, pointed out that it is not really possible to speak of Pilgerodendron uviferum forests because of the small size of the stands.

3) High-Andean dwarf woodlands (Fig. 5C), consisting of deciduous krummholz communities at the snowline, forming a continuous belt at upper elevations. Krummholz dominated by $N$. pumilio are distributed in the Baker River basin, while krummholz dominated by $N$. antarctica are located in the Pascua River basin. Hambleton (1936) mentioned the presence of krummholz communities in the Baker basin above 1,000 m altitude, while Pisano (1972), based on Davison's data from New Zealand's second expedition to the North Patagonian Ice Field, described N. antarctica krummholz communities with Empetrum rubrum. This last species, however, has minor importance with regard to frequency and cover in our plots.

DisTURBANCE PATTERNS AFFECTING WOODLAND COMMUNITIES Four major types of current human disturbances affecting the woodland communities have been observed: 1) logging for fuel wood and construction timber, 2) overgrazing of ground vegetation by livestock, 3) road widening in forested lands and 4) invasion of some stands by Pinus contorta. All of these disturbances are confined to the Baker basin where roads, exotic plantations and human population are present. The vegetation in the Pascua basin, however, remains completely pristine. The disturbances occurring in the Baker basin are slowly changing the structure and composition of the woodland communities by means of an increase in the introduction of exotic plant species, reduction in cover of native dominant ones, mortality of tree seedlings and erosion, among other effects, as occurs in 
other similarly impacted forest ecosystems (Ramírez et al. 1981, Raffaele et al. 2007, Quintanilla 2008, Speziale et al. 2010, Vidal \& Reif 2011). The fact that exotic species occur in the Baker basin supports the idea that a process of biotic homogeneization of their vegetation communities (sensu Olden \& Rooney 2006) may occur, leading to an increase in similarity among regional floras. Although this study shows that roads contribute little as corridors for exotic species, the sample design cannot distinguish among the synergic effects of the disturbances mentioned above.

The fact that these disturbances are confined to the Baker River basin is related to the history of the place. A dramatic transformation of forest into open vegetation areas was carried out between 1930-1950 in the northern part of the Aysén Region, when Chilean-European settlers burned great extensions of woodlands for livestock production (CONAF 2006). More humid and inaccessible forests in southern areas and archipelagic regions, however, remained undisturbed (Quintanilla 2008). Thus, human establishment and road construction were possible only in northern areas where it was possible to carry out livestock activities. Until now, only a few studies have aimed to evaluate the resiliency of these forests after fire disturbance (e.g. Quintanilla 2008), and it seems that few burned forest stands were able to recover after fire. This led to a structural change in the landscape, where anthropogenic prairies, post-fire shrublands and parklike stands developed a heterogeneous landscape matrix. Moreover, the current influence of livestock in forests through extensive grazing practices are leading to changes in the understory composition such as an increment in biodiversity due to exotic plant species (Sánchez-Jardón et al. 2010), especially in open canopy stands. However, it is interesting to note the low levels of biological invasions reported for our study in unburned forest stands and the relatively higher species richness and diversity recorded for forests in the Pascua basin.

Although our objective here is not directly to evaluate the effects of past or current disturbances, it seems appropriate to highlight the apparently low level of disturbances affecting these forests, as we show through the biodiversity indicators evaluated. This situation appears to offer even an interesting opportunity for researchers to evaluate undisturbed biogeographical and ecological patterns and processes occurring at one of the most remote, isolated and unpolluted landscapes in southern Chile.

\section{ACKNOWLEDGMENTS}

This project it was financed by the contract CA 012.05 UACH-UCONC-HIDROAYSEN. Thanks to Alejandra Jiménez and Ernesto Teneb for field support. Prof. Dr. Albert Reif (Freiburg University) and Prof. Dr. Jurgen Huss (Freiburg University) commented on an earlier version of the manuscript. Thanks to Juana Palma (Freiburg University) for advising on the use of R software. The first two authors thank the CONICYT and DAAD for the funding provided to doctoral studies at the Albert-Ludwigs University in Freiburg, Germany.

\section{BIBLIOGRAPHY}

Amigo, J. \& C. Ramírez. 1998. A bioclimatic classification of Chile: woodland communities in the temperate zone. Plant Ecology 136: 9-26.

Amigo, J., C. Ramírez, \& V. Quintanilla. 2004. The Nothofagus nitida (Phil.) Krasser woodlands of Southern Chile in the northern half of their range: phytosociological position. Acta Botanica Gallica 151: 3-31.

Cabrera, A. 1949. El género Senecio en Chile. Lilloa 15: 27-501.

CONAF 2006. Consideraciones generales respecto a los incendios forestales en Aisén. Informe técnico. Departamento del fuego de la XI Región.

Du RiEtZ, G.E. 1960. Remarks on the botany of the Southern Cold Temperate Zone. Proceedings of the Royal Society of London 152: 500-507.

Dufrêne, M. \& P. Legendre. 1997. Species assemblages and indicator species: the need for a flexible asymmetrical approach. Ecological Monographs 67: 345-366.

Fuenzalida, H. \& E. Pisano. 1967. Biogeografía. En: CORFO (eds.) Geografía Económica de Chile, pp. 228-267. Corporación de Fomento de la Producción, Fundación Pedro Aguirre Cerda, Santiago.

GodLey, E.J. 1960. The botany of southern Chile in relation to New Zealand and the Subantarctic. Proceedings of the Royal Society of London 152: 457-475.

Hambleton, S. 1936. La vegetación del Canal y Río Baker (Patagonia Occidental). Revista Argentina de Agronomía 3: $159-173$.

Hammer, O., D. Harper \& P. Ryan. 2001. PAST: Paleontological statistics software package for education and data analysis. Palaeontología electrónica 4: 1-9.

Henríquez, J., E. Pisano \& C. Marticorena. 1995. Catálogo de la flora vascular de Magallanes (XII Región), Chile. Anales del Instituto de la Patagonia 23: 5-30.

Holdgate, M.W. 1960. Biology of the Southern Cold Temperate Zone. Nature 185: 204-206.

Hueck, K. 1978. Los bosques de Sudamérica. Ecología, composición e importancia económica. Sociedad Alemana de Cooperación Técnica (GZT), Eschborn. 476 pp.

Landrum, L. 2003. Berberidaceae. En: C. Marticorena \& R. Rodríguez (eds.), Flora de Chile. pp 1-23. Universidad de Concepción.

LAPIN, M., \& V. Barnes. 1995. Using the landscape ecosystem approach to assess species and ecosystem diversity. Conservation Biology 9: 1148-1158.

Luebert, F., \& P. Pliscoff. 2006. Sinopsis bioclimática y vegetacional de Chile. Editorial Universitaria, Santiago de Chile. 316 pp.

Marticorena, A. 2006. Revisión del género Acaena (Rosaceae) en Chile. Annals of the Missouri Botanical Garden 93: 412454. 
Martínez-Harms, M.J., \& R. Gajardo. 1998. Ecosystem vague in the Western Patagonia protected areas. Journal of Nature Conservation 16: 72-87.

Matthei, O. 1995. Manual de las malezas que crecen en Chile. Santiago, Chile. Alfabeta Impresiones, $545 \mathrm{pp}$.

McCune, B., \& J.B. Grace. 2002. Analysis of ecological communities. MjM Software Design (ed.). 300 pp.

Moore, D. 1982. Flora of Tierra del Fuego. Shrosphire, England. Anthony Nelson. Missouri, USA. Missouri Botanical Garden. 396 pp.

Moreno, C.E. 2001. Métodos para medir la biodiversidad. M\&T Manuales y tesis SEA. Vol 1, Zaragoza, 84 pp.

Mueller-Dombois, D., \& H. Ellenberg. 1974. Aims and methods of vegetation ecology. John Wiley \& Sons, New York. 547 pp.

MuÑoz-Schick M. 1980. Flora del Parque Nacional Puyehue. Santiago, Chile. Editorial Universitaria. 557 pp.

Noss, R.F. 1990. Indicators for biodiversity monitoring: a hierarchical approach. Conservation Biology 4: 355-364.

Oberdorfer, E. 1960. Die Wiessenlandschaft Süd-Chile. Die Umschau 12: 370-372.

Olden, J.D., \& T.P. Rooney. 2006. On defining and quantifying biotic homogenization. Global Ecology and Biogeography 15: 113-120.

PISANO, E. 1972. Algunos resultados botánicos de la II Expedición neozelandesa al Hielo Nor-Patagónico, 1971-1972. Anales del Instituto de la Patagonia 3: 131-160.

Quintanilla, V. 2008. Estado de recuperación del bosque nativo en una cuenca nordpatagónica de Chile, perturbada por grandes fuegos acaecidos 50 años atrás (44 - 45 S). Revista Geográfica del Norte Grande 39: 73-92.

Raffaele, E., Kitzberger, T., \& T. Veblen. 2007. Interactive effects of introduced herbivores and post-flowering dieoff of bamboos in Patagonian Nothofagus forests. Journal of Vegetation Science 18: 371-378.

Ramírez, C., Godoy, R., Eldrige, W., \& N. Pacheco. 1981. Impacto ecológico del ciervo rojo sobre el bosque de olivillo en Osorno, Chile. Anales del Museo de Historia Natural (Chile): 197-215.

Ramírez, C., San Martín, C., Oyarzún, A. \& H. Figueroa. 1997. Morpho-ecological study on the South American species of the genus Nothofagus. Plant Ecology 130: 101-109.

Reiche, K. 1934. Geografía botánica de Chile. Imprenta Universitaria, Santiago, 149 pp.

Rodríguez, R., \& M. QueZada. 2003. Fagaceae. En: C. Marticorena \& R. Rodríguez (eds.), Flora de Chile. pp. 64-78. Universidad de Concepción, Chile.

Rodríguez, R., Marticorena, A., \& E. Teneb. 2008. Plantas vasculares de los Ríos Baker y Pascua, Región de Aysén. Gayana Botánica 65: 39-70.

Ruíz, E. 2001. Ranunculaceae. En: C. Marticorena \& R. Rodríguez (eds.), Flora de Chile. pp. 40-84. Universidad de Concepción, Chile.

Sánchez-Jardón, L., B. Acosta, A. del Pozo, M.A. Casado, C. Ovalle, H.F. Eliazade, H. Hepp \& J.M. de Miguel. 2010. Grassland productivity and diversity on a tree cover gradient in Nothofagus pumilio in NW Patagonia. Agriculture, Ecosystems and Environment 137. 213-218.

SkottsberG, C. 1960. Remarks on the plant geography of the Southern Cold Temperate Zone. Proceedings of the Royal Society of London 152: 447-457.

Speziale, K.L., Ruggiero, A., \& C. Ezcurra. 2010. Plant species richness-environment relationships across the SubantarticPatagonian transition zone. Journal of Biogeography 37: 449-464.

Veblen, T.T. \& F.M. Schlegel. 1982. Reseña ecológica de los bosques del sur de Chile. Bosque 4: 73-115.

VIDAL, O.J. \& A. REIF. 2011. Effect of a tourist-ignited wildfire on Nothofagus pumilio forests at Torres del Paine biosphere reserve, Chile (Southern Patagonia). Bosque 32: 64-76.

Wikum, D.A. \& G.F. Shanholtzer. 1978. Application of BraunBlanquet cover-abundance scale for vegetation analysis in land-development studies. Environmental Management 2: 323-32.

ANNEX 1. Diagnostic species for each woodland community based on the indicator species values and $p$ values $(* \leq 0.05 ; * * \leq 0.005: * * *$ $\leq 0.001)$.

ANEXo 1. Especies diagnósticas para cada comunidad leñosa basado en los valores indicadores y sus correspondientes valores de probabilidad $p(* \leq 0,05 ; * * \leq 0,005: * * * \leq 0,001)$.

\begin{tabular}{|c|c|c|c|c|}
\hline Community type / Species & Family & Origin & Life Form & ISA Value \\
\hline \multicolumn{5}{|l|}{ Nothofagus nitida forests } \\
\hline Azara lanceolada Hook.f. & Flacourtiaceae & Native & Phanerophyte & $0.39 * * *$ \\
\hline Blechnum magellanicum (Desv.) Mett. & Blechnaceae & Native & Hemicryptophyte & $0.29 * *$ \\
\hline Campsidium valdivianum (Phil.) Skottsb. & Bignoniaceae & Native & Epiphyte & $0.41 * * *$ \\
\hline Drimys winteri J.R.Forst. et G. Forst. & Winteraceae & Native & Phanerophyte & $0.38 * * *$ \\
\hline Griselina ruscifolia (Clos) Ball. & Griseliniaceae & Native & Epiphyte & $0.56 * * *$ \\
\hline Hymenophyllum krauseanum Phil. & Hymenophyllaceae & Native & Ephiphyte & $0.70 * * *$ \\
\hline Lomatia ferruginea (Cav.) R. Br. & Proteaceae & Native & Phanerophyte & $0.23 * * *$ \\
\hline Mitraria coccinea Cav. & Gesneriaceae & Native & Epiphyte & $0.47 * * *$ \\
\hline Nothofagus nitida (Phil.) Krasser & Nothofagaceae & Native & Phanerophyte & $1.00 * * *$ \\
\hline Podocarpus nubigena Lindl. & Podocarpaceae & Native & Phanerophyte & $0.50 * * *$ \\
\hline Pseudopanax laetevirens (Gay) Franchet & Araliaceae & Native & Phanerophyte & $0.46 * * *$ \\
\hline Weinmannia trichosperma Cav. & Cunoniaceae & Native & Phanerophyte & $0.22 * * *$ \\
\hline
\end{tabular}




\begin{tabular}{|c|c|c|c|c|}
\hline Community type / Species & Family & Origin & Life Form & ISA Value \\
\hline \multicolumn{5}{|l|}{ Pilgerodendron uviferum forests } \\
\hline Berberis ilicifolia L.f. & Berberidaceae & Native & Phanerophyte & $0.40 * * *$ \\
\hline Carex magellanica Lam. & Cyperaceae & Native & Hemicryptophyte & $0.49 * * *$ \\
\hline Empetrum rubrum Vahl ex Willd. & Empetraceae & Native & Chamaephyte & $0.49 * * *$ \\
\hline Gaimardia australis Gaudich. & Centrolepidaceae & Native & Chamaephyte & $0.29 * *$ \\
\hline Hypochaeris palustris (Phil.) De Wild. & Asteraceae & Native & Hemicryptophyte & $0.29 * *$ \\
\hline Juncus microcephalus Kunth & Juncaceae & Native & Hemicryptophyte & $0.29 * *$ \\
\hline Lebetanthus myrsinites (Lam.) Dusen & Epacridaceae & Native & Phanerophyte & $0.48 * * *$ \\
\hline Macrachaenium gracile Hook.f. & Asteraceae & Native & Hemicryptophyte & $0.40 * *$ \\
\hline Myrteola nummularia (Poir.) O.Berg & Myrtaceae & Native & Chamaephyte & $0.31 * *$ \\
\hline Oreobolus obtusangulus Gaudich. & Cyperaceae & Native & Hemicryptophyte & $0.57 * * *$ \\
\hline Philesia magellanica J.F.Gmel. & Philesiaceae & Native & Epiphyte & $0.44 *$ \\
\hline Pilgerodendron uviferum (D.Don) Florin & Cupressaceae & Native & Phanerophyte & $0.79 * *$ \\
\hline \multicolumn{5}{|l|}{ Nothofagus betuloides forests } \\
\hline Desfontainia fulgens D.Don & Desfontainiaceae & Native & Phanerophyte & $0.38 * * *$ \\
\hline Escallonia rubra (Ruiz et Pav.) Pers. & Escalloniaceae & Native & Phanerophyte & $0.24 * * *$ \\
\hline Hymenophyllum tortuosum Hook.et Grev. & Hymenophyllaceae & Native & Epiphyte & $0.22 *$ \\
\hline Luzuriaga marginata (Banks et Sol. ex Gaertn.) Benth. & Luzuriagaceae & Native & Epiphyte & $0.30 * *$ \\
\hline Nothofagus betuloides (Mirbel) Oersted & Nothofagaceae & Native & Phanerophyte & $0.70 * * *$ \\
\hline Schoenus andinus (Phil.) H.Pfeiffer & Cyperaceae & Native & Hemicryptophyte & $0.20 *$ \\
\hline Serpyllopsis caespitosa (Gaudich.) C.Chr. & Hymenophyllaceae & Native & Epiphyte & $0.50 * * *$ \\
\hline Sticherus quadripartitus (Poir.) Ching & Gleicheniaceae & Native & Hemicryptophyte & $0.22 * *$ \\
\hline \multicolumn{5}{|l|}{ Nothofagus pumilio forests } \\
\hline Adenocaulon chilense Poepp. ex Less. & Asteraceae & Native & Hemicryptophyte & $0.25 * *$ \\
\hline Codonorchis lessonii (Brongn.) Lindl. & Orchidaceae & Native & Geophyte & $0.18 *$ \\
\hline Lycopodium magellanicum (P.Beauv.) Sw. & Lycopodiaceae & Native & Hemicryptophyte & $0.16 *$ \\
\hline Maytenus disticha (Hook.f.) Urban & Celastraceae & Native & Phanerophyte & $0.43 * * *$ \\
\hline Nothofagus pumilio (Poepp. et Endl.) Krasser & Nothofagaceae & Native & Phanerophyte & $0.55 * * *$ \\
\hline Osmorhiza chilensis Hook et Arn. & Apiaceae & Native & Hemicryptophyte & $0.23 * *$ \\
\hline Poa pratensis $\mathrm{L}$. & Poaceae & Exotic & Hemicryptophyte & $0.20 * *$ \\
\hline Viola maculata Cav. & Violaceae & Native & Hemicryptophyte & $0.49 * * *$ \\
\hline \multicolumn{5}{|l|}{ Nothofagus pumilio krummholz } \\
\hline Gaultheria pumila (L.f.) D.J.Middleton & Ericaceae & Native & Chamaephyte & $0.34 * * *$ \\
\hline Rubus geoides $\mathrm{Sm}$. & Rosaceae & Native & Hemicryptophyte & $0.29 * *$ \\
\hline \multicolumn{5}{|l|}{ Nothofagus dombeyi forests } \\
\hline Nothofagus dombeyi (Mirb.) Oerst. & Nothofagaceae & Native & Phanerophyte & $0.89 * * *$ \\
\hline Ribes magellanicum Poir. & Grossulariaceae & Native & Phanerophyte & $0.18 *$ \\
\hline Viola reichei Skottsb. & Violaceae & Native & Hemicryptophyte & $0.16 *$ \\
\hline \multicolumn{5}{|l|}{ Embothrium coccineum shrublands } \\
\hline Baccharis magellanica (Lam.) Pers. & Asteraceae & Native & Chamaephyte & $0.49 * * *$ \\
\hline Embothrium coccineum J.R.Forst. et G.Forst. & Proteaceae & Native & Phanerophyte & $0.60 * * *$ \\
\hline Escallonia rosea Griseb. & Escalloniaceae & Native & Phanerophyte & $0.51 * * *$ \\
\hline Gaultheria mucronata (L.f.) Hook. et Arn. & Ericaceae & Native & Phanerophyte & $0.28 * * *$ \\
\hline Gavilea odoratissima Poepp. & Orchidaceae & Native & Geophyte & $0.34 * * *$ \\
\hline Lycopodium paniculatum Desv. & Lycopodiaceae & Native & Hemicryptophyte & $0.39 * * *$ \\
\hline \multicolumn{5}{|l|}{ Nothofagus antarctica forests } \\
\hline Blechnum penna-marina (Poir.) Kuhn & Blechnaceae & Native & Hemicryptophyte & $0.20 * *$ \\
\hline Chusquea culeou E. Desv. & Poaceae & Native & Phanerophyte & $0.76 * * *$ \\
\hline Escallonia virgata (Ruiz et Pav.) Pers. & Escalloniaceae & Native & Phanerophyte & $0.40 * * *$ \\
\hline
\end{tabular}




\begin{tabular}{|c|c|c|c|c|}
\hline Community type / Species & Family & Origin & Life Form & ISA Value \\
\hline Ranunculus trullifolius Hook.f. & Ranunculaceae & Native & Hemicryptophyte & $0.18 * * *$ \\
\hline Scirpus inundatus (R.Br.) Poir. & Cyperaceae & Native & Hemicryptophyte & $0.15 *$ \\
\hline \multicolumn{5}{|l|}{ Nothofagus antarctica shrublands } \\
\hline Achillea millefolium $\mathrm{L}$. & Asteraceae & Exotic & Hemicryptophyte & $0.26 *$ \\
\hline Anemone multifida Poir. & Ranunculaceae & Native & Hemicryptophyte & $0.40 * * *$ \\
\hline Carduus nutans L. & Asteraceae & Exotic & Therophyte & $0.13 *$ \\
\hline Cerastium arvense $\mathrm{L}$. & Caryophyllaceae & Exotic & Hemicryptophyte & $0.16 *$ \\
\hline Discaria chacaye (G.Don) Tortosa & Rhamnaceae & Native & Phanerophyte & $0.29 * *$ \\
\hline Festuca pyrogea Speg. & Poaceae & Native & Hemicryptophyte & $0.27 *$ \\
\hline Fragaria chiloensis (L.) Duch. & Rosaceae & Native & Hemicryptophyte & $0.23 * *$ \\
\hline Geum magellanicum Pers. & Rosaceae & Native & Hemicryptophyte & $0.18 *$ \\
\hline Jarava psylantha (Speg.) Penail. & Poaceae & Native & Hemicriptophyte & $0.16 *$ \\
\hline Misodendrum punctulatum Banks ex DC. & Misodendraceae & Native & Epiphyte & $0.24 * *$ \\
\hline Phacelia secunda J.F.Gmel. & Hydrophyllaceae & Native & Hemicryptophyte & $0.17 *$ \\
\hline Ribes cucullatum Hook. et Arn. & Grossulariaceae & Native & Phanerophyte & $0.18 * *$ \\
\hline Rumex acetosella $\mathrm{L}$. & Polygonaceae & Exotic & Hemicryptophyte & $0.25 * *$ \\
\hline \multicolumn{5}{|l|}{ Nothofagus antarctica krummholz } \\
\hline Acaena pumila Vahl & Rosaceae & Native & Hemicryptophyte & $0.38 * *$ \\
\hline Bolax caespitosa Hombr. et Jacquinot & Apiaceae & Native & Chamaephyte & $0.60 * *$ \\
\hline Caltha dionaeifolia Hook.f. & Ranunculaceae & Native & Hemicryptophyte & $0.40 * * *$ \\
\hline Gunnera magellanica Lam. & Gunneraceae & Native & Hemicryptophyte & $0.62 * * *$ \\
\hline Marsippospermum grandiflorum (L.f.) Hook. & Juncaceae & Native & Hemicryptophyte & $0.30 * *$ \\
\hline Nothofagus antarctica (G.Forst.) Oerst. & Nothofagaceae & Native & Phanerophyte & $0.31 * * *$ \\
\hline Perezia linearis Less. & Asteraceae & Native & Hemicryptophyte & $0.18 *$ \\
\hline Senecio acanthifolius Hombr. et Jacquinot & Asteraceae & Native & Hemicryptophyte & $0.92 * * *$ \\
\hline Senecio darwinii Hook et Arn. & Asteraceae & Native & Chamaephyte & $0.40 * *$ \\
\hline \multicolumn{5}{|l|}{ Pinus contorta plantations } \\
\hline Agrostis stolonifera L. & Poaceae & Exotic & Hemicryptophyte & $0.87 * * *$ \\
\hline Nertera granadensis (Mutis ex L.f.) Druce & Rubiaceae & Native & Hemicryptophyte & $0.51 * * *$ \\
\hline Pinus contorta Douglas ex Loudon & Pinaceae & Exotic & Phanerophyte & $1.00 * * *$ \\
\hline
\end{tabular}

Recibido: 28.02.11

Aceptado: 23.05.11 